\title{
PEMBELAJARAN ICARE (INRODUCTION, CONNECT, APPLY, REFLECT, EXTEND) DALAM TUTORIAL ONLINE UNTUK MENINGKATKAN KEMAMPUAN PEMECAHAN MASALAH MATEMATIS MAHASISWA UT
}

\author{
Oleh: \\ 1) Yumiati, ${ }^{2)}$ Endang Wahyuningrum \\ ${ }^{1,2)}$ Pendidikan Matematika Universitas Terbuka \\ ${ }^{1}$ yumi@ut.ac.id, ${ }^{2}$ endangningrum@gmail.com
}

\begin{abstract}
ABSTRAK
Makalah ini membahas tentang penerapan model pembelajaran ICARE (inroduction, connect, apply, reflect, dan extend) dalam tutorial online untuk meningkatkan kemampuan pemecahan masalah matematis mahasiswa program studi pendidikan matematika Universitas Terbuka (UT). Tutorial online merupakan layanan bantuan belajar berbasis TIK yang disediakan UT sebagai salah satu bentuk bantuan belajar sistem pendidikan jarak jauh. Melalui kajian pustaka dipaparkan bagaimana ICARE dijastifikasi sebagai model pembelajaran yang dapat membuat pembelajaran e-learning efektif meningkatkan kemampuan pemecahan masalah matematis
\end{abstract}

Kata Kunci : Kemampuan pemecahan masalah matematis, pembelajaran ICARE.

\begin{abstract}
This paper discusses the application of ICARE (inroduction, connect, apply, reflect, and extend) learning models in the online tutorials to improve mathematical problem-solving abilities of students of mathematics education courses Universitas Terbuka (UT). Online tutorial is based learning support services information and communication technology provided UT as one form of learning support system of distance education. Through literature review described how ICARE justified as a learning model that can create elearning effectively to improve mathematical problem-solving abilities.
\end{abstract}

Keywords: Mathematical problem-solveing abilities, ICARE learning models.

\section{PENDAHULUAN}

Universitas Terbuka (UT) merupakan universitas yang menerapkan sistem pendidikan terbuka dan jarak jauh (PTJJ). Salah satu layanan bantuan belajar yang disediakan UT adalah tutorial. UT menyelenggarakan dua model tutorial, yaitu tutorial online (Tuton) berbasis jaringan internet dan tutorial tatap muka (TTM).

Di dunia pendidikan, pemanfaatan teknologi informasi dan komunikasi (TIK) berjalan sangat cepat untuk kepentingan administrasi, manajemen, dan 
pembelajaran. Dalam konteks PTJJ, TIK dapat dimanfaatkan untuk tuton. Tuton memungkinkan mahasiswa berkomunikasi dan berinteraksi dengan mahasiswa lain dan/atau tutor/dosen di mana saja dan kapan saja, tanpa terkendala jarak, ruang, dan waktu. Dengan cara ini, UT diharapkan dapat meningkatkan dukungan belajar bagi mahasiswa yang tersebar di seluruh pelosok tanah air bahkan sampai ke luar negeri.

Dalam pembelajaran matematika, kemampuan pemecahan masalah merupakan salah satu kemampuan yang harus dikuasai siswa (NCTM, 2000). Kemampuan pemecahan masalah merupakan tujuan umum pembelajaran matematika, bahkan sebagai jantungnya matematika (Branca dalam Krulik \& Reys, 1980). Wahyudin (2003) juga mengatakan bahwa pemecahan masalah bukan sekedar keterampilan untuk diajarkan dan digunakan dalam matematika tetapi juga merupakan keterampilan yang akan dibawa pada masalah-masalah keseharian siswa atau situasi-situasi pembuatan keputusan. Masalah yang sering terjadi dalam pembelajaran matematika adalah siswa sering melakukan kesalahan dalam menyelesaikan masalah yang non rutin yang mengakibatkan kemampuan pemecahan masalah mereka rendah (Kesumawati, 2010).

Kemampuan pemecahan masalah matematis bukanlah kemampuan yang dapat diperoleh seketika, namun harus dibangun melalui latihan dan pembiasaan yang dilakukan secara terus menerus. Oleh karena itu salah satu langkah yang dapat dilakukan adalah memilih model pembelajaran yang dapat memotivasi siswa untuk mampu menyelesaikan masalah matematik.

Strategi pengajaran yang efektif dalam lingkungan $e$-learning dan memuaskan bagi siswa adalah model pembelajaran ICARE (Salyers, et.al., 2010). Model Pembelajaran TIK yang mengedepankan ciri: aktif, kreatif, dan menyenangkan (joyful learning) adalah model ICARE (Wahyudin, 2010). ICARE merupakan kepanjangan inroduction, connect, apply, reflect, dan extend. Kegiatan-kegiatan yang dilakukan mahasiswa pada setiap tahapan pembelajaran ICARE membutuhkan kemampuan pemecahan masalah yang baik, sehingga melalui pembelajaran ICARE diharapakan kemampuan pemecahan masalah mahasiswa dapat terlatih.

\section{KAJIAN TEORI}

\section{Pemecahan Masalah Matematis}

Gerakan perubahan paradigma dalam pendidikan matematika saat ini mengarah pada penyertaan pemecahan masalah (problem solving) sebagai komponen utama dalam kurikulum. Problem solving merupakan tujuan utama dari semua pembelajaran matematika dan merupakan bagian integral dari semua aktivitas matematika. Hal ini sesuai dengan pernyataan Suryadi (2012) yang mengatakan bahwa dalam kegiatan bermatematika, pada dasarnya anak akan berhadapan dengan dua hal yakni masalah-masalah apa yang mungkin muncul atau diajukan dari sejumlah fakta 
yang dihadapi serta bagaimana menyelesaikan masalah tersebut (problem solving). Melalui kegiatan problem solving, anak dapat mengembangkan kemampuannya untuk menyelesaikan permasalahan tidak rutin yang memuat berbagai tuntutan kemampuan berpikir termasuk yang tingkatannya lebih tinggi.

Polya (1973) mendefinisikan pemecahan masalah sebagai usaha mencari jalan keluar dari suatu kesulitan guna mencapai suatu tujuan yang tidak segera dapat dicapai. Dengan demikian, pemecahan masalah meruapakn suatu intelektual yang tinggi.

Untuk mengukur kemampuan pemecahan masalah matematis, tahapan-tahapan pemecahan masalah dalam model-model pemecahan masalah matematis yang dikemukakan oleh Polya (1973) dapat dipandang sebagai aspek-aspek kemampuan pemecahan masalah matematis. Aspek-aspek itu adalah memahami masalah, membuat model matematik dan menyusun strategi pemecahan masalah, menyelesaikan model matematik atau mengimplementasikan strategi pemecahan masalah, dan menginterpretasi solusi.

Kemampuan pemecahan masalah matematis siswa dapat ditingkatkan dengan memberikannya masalah matematika yang jawabannya tidak secara langsung didapatkan siswa tetapi membutuhkan pemikiran yang lebih dalam. Contohnya sebagai berikut.

Sebuah bilangan yang terdiri atas 2 angka, nilainya 7 kali besar jumlah angkaangkanya. Jika kedua angka ditukarkan, maka diperoleh bilangan baru yang nilainya 18 lebih dari jumlah angka-angkanya. Berapakah bilangan itu?

Penyelesaian masalah ini menuntut siswa membaca dan memahami masalah, kemudian membuat model matematika, membuat strategi penyelesaiannya, setelah itu barulah siswa dapat menyelesaikan masalah tersebut.

\section{Pembelajaran ICARE}

Model ICARE didesain untuk pembelajaran online. Seperti yang diungkapkan oleh Pastor dalam Wahyudin \& Susilana (2012), ICARE dirancang untuk membantu siswa belajar melalui online secara efektif. Prinsip ICARE adalah menyajikan materi esensial untuk setiap topik.

ICARE merupakan singkatan dari Introduction (pengenalan), Connect (menghubungkan), Apply (menerapkan dan mempraktikkan), Reflect (merefleksikan), dan Extend (memperluas dan evaluasi). Menurut Wahyudin \& Susilana (2012), tahapan dalam pembelajaran ICARE mengikuti singkatan tersebut. 


\section{Tahap I: Introduction}

Pada tahap ini dijelaskan garis besar isi materi pelajaran secara keseluruhan, tujuan yang akan dicapai, materi prasyarat, waktu yang diperlukan, kegiatan dan evaluasi yang akan dilakukan, serta bahan bacaan yang diperlukan. Pada tahap ini dimaksudkan juga untuk mengetahui sejauhmana pemahaman dan minat siswa dalam mengikuti pembelajaran yang akan diberikan.

\section{Tahap II: Connect}

Pada tahap ini diperkenalkan fakta-fakta, konsep, prinsip, dan/atau proses yang berkaitan dengan materi yang akan dipelajari. Dalam kegiatan ini memberi kesempatan siswa untuk menemukan fakta-fakta, konsep, prinsip sendiri. Ada 4 langkah yang disarankan Pastor dalam Wahyudin \& Susilana (2012) pada tahap ini, yaitu: 1) Membagi materi ke dalam sub-sub topik untuk memudahkan siswa memahami informasi baru; 2) Menghubungkan informasi kepada tugas-tugas yang berkaitan dengan dunia nyata dan pengetahuan sebelumnya; 3) Memfasilitasi siswa dengan informasi secara bertahap dan berkesinambungan sehingga merupakan rangkaian belajar yang bermakna; 4) Menyajikan bahan yang akan diberikan secara lebih menyenangkan dengan berbagai pendekatan dan penggunaan media.

\section{Tahap III: Apply}

Tahap ini memberikan tantangan dan kegiatan yang memungkinkan siswa untuk menerapkan pengetahuan yang mereka dapatkan pada tahap II dengan memberikan masalah-masalah yang berkaitan dengan dunia nyata. Kegiatan simulasi, permainan, atau menebak sangat baik dilakukan pada tahap ini. Kegiatan lain yang dapat juga dilakukan pada tahap ini adalah meminta siswa mencari situs lain yang relevan.

\section{Tahap IV: Reflect}

Pada tahap ini siswa diminta untuk merenungkan tentang apa yang telah mereka pelajari, apa yang mereka peroleh dan pengalaman yang didapatkan dari tahap connect sampai apply. Bantulah siswa mengorganisasikan pikiran mereka tentang apa yang baru saja mereka pelajari dengan memberikan kesempatan kepada mereka untuk mendiskusikan dan memperluas informasi. Hal ini dapat dilakukan dengan beberapa cara. Mendiskusikan tentang pembelajaran online, meminta siswa membuat peta konsep, merepresentasikan secara visual hubungan antar konsep. Peta konsep sangat berguna bagi siswa untuk membantu memperluas informasi baru .

\section{Tahap V: Extend}

Pada tahap ini memberi kesempatan siswa memperluas pengetahuan yang telah diperoleh dengan memberi tantangan masalah yang lebih luas. Ada dua kegiatan utama pada tahap akhir ini, yaitu: 1) Memberikan kegiatan pengayaan dan 
remediasi; 2) Memberikan evaluasi terhadap penguasaan materi siswa dan evaluasi terhadap bahan ajar atau desain pembelajaran.

Pembelajaran ICARE yang didesain agar pembelajaran online efektif diduga dapat meningkatkan kemampuan pemecahan masalah matematis. Hal ini dapat dijelaskan mulai tahap kedua pembelajaran, yaitu sebagai berikut.

Tahap kedua pembelajaran adalah tahap connect. Pada tahap ini terdapat langkah menghubungkan informasi baru kepada tugas-tugas yang berkaitan dengan dunia nyata dan pengetahuan sebelumnya, hal ini berkaitan dengan penyelesaian masalah non rutin yang merupakan bagian dari pemecahan masalah matematis. Demikian juga pada tahap apply biasanya disajikan masalah-masalah yang berkaitan dengan kehidupan sehari-hari yang penyelesaiannya membutuhkan kemampuan pemecahan masalah. Pada tahap reflect dan extend, diperlukan kemampuan siswa dalam memecahkan masalah, karena pada kedua tahapan tersebut diberikan kesempatan siswa untuk memperluas informasi dan memperkaya pengetahuan.

\section{Tutorial Online (Tuton)}

Universitas Terbuka menyediakan dua bentuk layanan tutorial, yaitu tutorial tatap muka (TTM) dan tutorial online (Tuton). Tuton adalah bantuan belajar yang diberikan kepada mahasiswa melalui media internet. Tutorial online diselenggarakan dengan tujuan (Tim UT, 2003): 1) mengoptimalkan pemanfaatan internet dalam memberikan layanan bantuan belajar kepada mahasiswa; 2) memungkinkan proses pembelajaran jarak jauh didesain lebih komunikatif dan interaktif; dan 3) memberi alternatif bagi mahasiswa yang memiliki akses internet memperoleh layanan bantuan belajar secara optimal.

Tutorial online dirancang untuk dilaksanakan selama 8 (delapan) minggu yang dimulai setelah penutupan masa registrasi. Aktivitas tutorial terdiri atas: 1) penyebaran materi inisiasi dari tutor kepada mahasiswa sebanyak 8 (delapan) kali (atau satu materi inisiasi per minggu); 2) pemberian materi diskusi dari tutor untuk setiap inisiasi; 3) pemberian sekurang-kurangnya 3 (tiga) tugas yang harus dikerjakan oleh mahasiswa; dan 4) aktivitas tanya jawab antara tutor dengan mahasiswa dan antar mahasiswa.

Contoh kegiatan pembelajaran ICARE dalam tutorial online sebagai berikut (hanya diberikan 3 langkah: introduction, connect, dan reflect). 


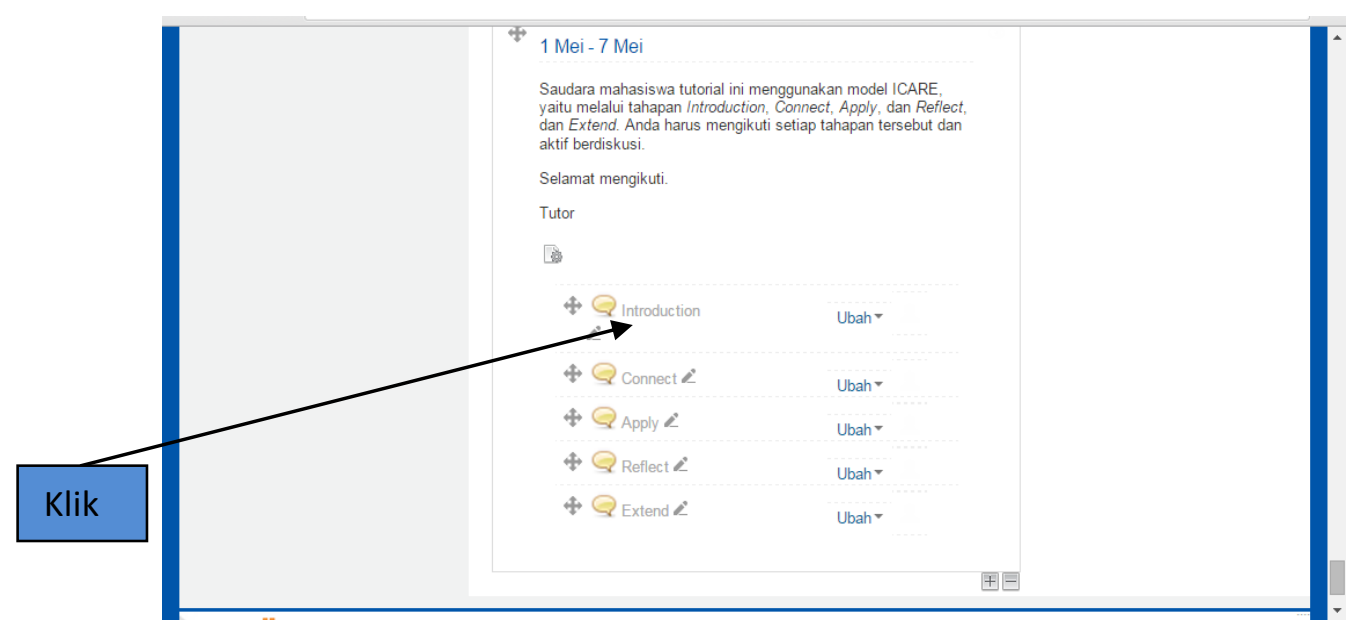

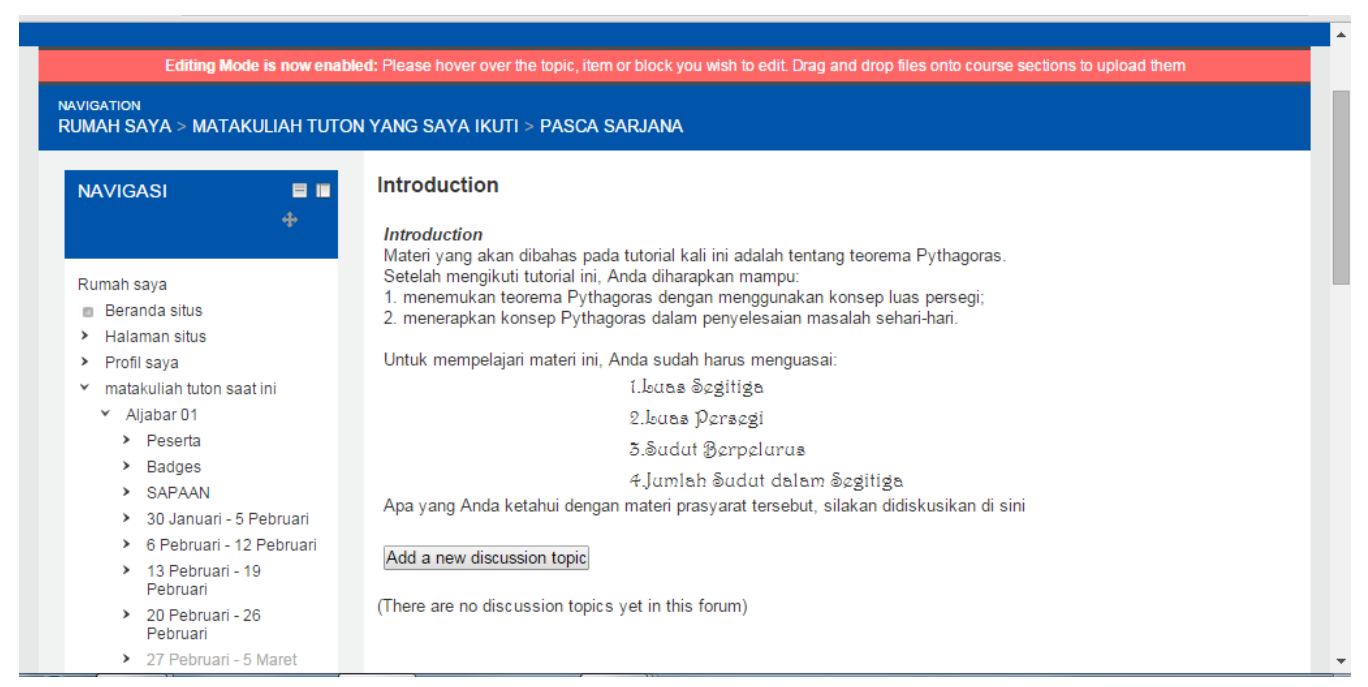




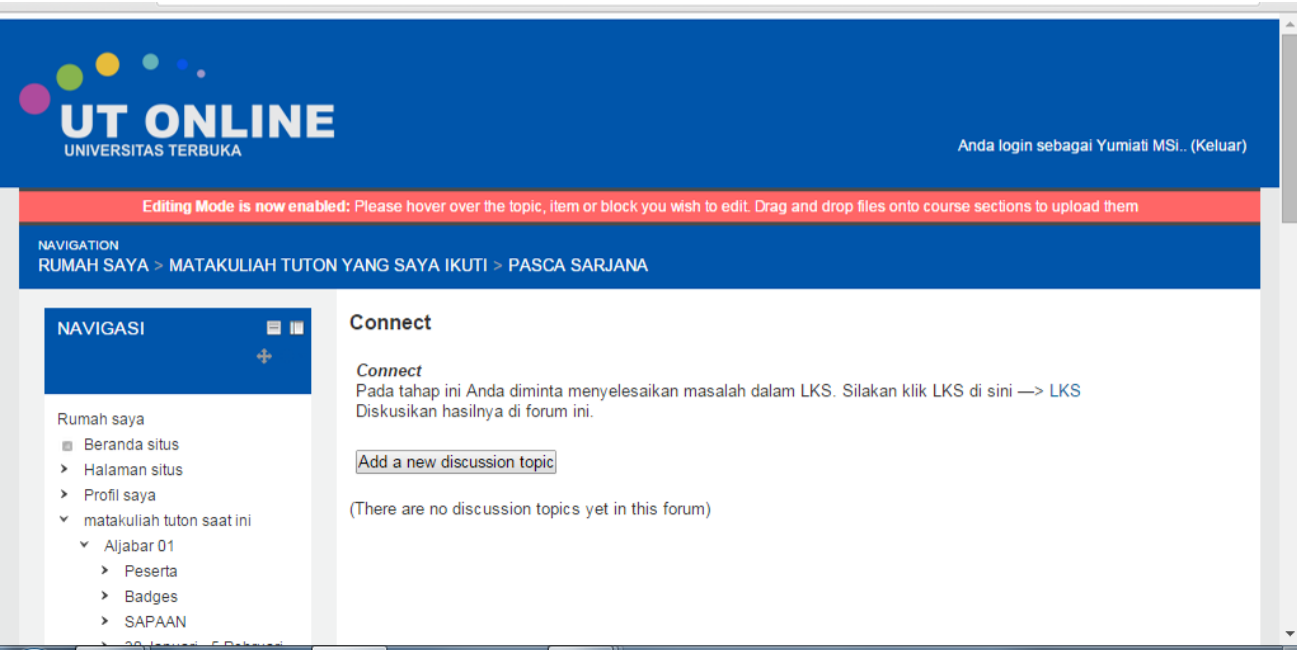

\section{UT ONLINE}

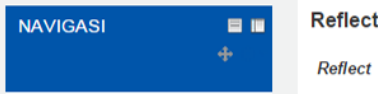

Rumah saya

- Beranda situs

> Halaman situs

> Profil saya

matakulian tuton saat ini

$\checkmark$ Aljabar 01

> Peserta

> Badges

> SAPAAN

30 Januari -5 Pebruari

> 6 Pebruari -12 Pebruari

- Lihat kembali LKS yang diberikan di tahap connect. Di situ terdapat pertanyaan mengapa PQRS merupakan persegi? Diskusikan dalam forum in

- Lihat kembali LKS yang diberikan pada tahap connect, apakah rumus Pythagoras hanya berlaku pada segitiga siku-siku? Diskusikan dalam forum ini

Berkan suatu contoh penerapan teorema Pythagoras dalam menentukan tinggi suatu bangunan. Diskusikan dalam forum in

Add a new discussion topic

(There are no discussion topics yet in this forum)

\section{DAFTAR PUSTAKA}

Krulik, S. \& Reys, R.E. (1980). Problem Solving in School Mathematics. Virginia: NCTM.

Kesumawati, N. (2010). Peningkatan Kemampuan Pemahaman, Pemecahan Masalah, dan Disposisi Matematis Siswa SMP melalui Pendekatan Pendidikan Matematika Realistik. Disertasi pada PPs UPI Bandung: Tidak diterbitkan.

National Council of Teacher of Mathematics. (2000). Principles and Standards for School Mathematics. Reston, VA: NCTM. 
Polya, G. (1973). How to Solve it. An new Aspect of Mathematical Method, Second Edition. New Jersey: Princeton University Press.

Tim UT. (2003). Pedoman Umum Tutorial. Jakarta: Universitas Terbuka.

Salyers, V., Carter, L., Barrett, P., Williams, L. (2010). Evaluating Student and Faculty Satisfaction with a Pedagogical Framework . Journal of Distance Education, Vol 24, no 3. AU Press, Athabasca University.

Suryadi, D. (2012). Membangun Budaya Baru dalam Berpikir Matematika. Bandung: Rizqi Press.

Wahyudin. (2003). Peranan Problem Solving. Makalah Seminar pada Technical Cooperation Project for Development of Mathematics and Science for Primary and Secondary Education in Indonesia. August 25, 2003.

Wahyudin, D. (2010). Model Pembelajaran ICARE pada Kurikulum Mata Pelajaran TIK di SMP (ICARE based Instructional Model on ICT Curriculum in Yunior Secondary School). Jurnal Penelitian Pendidikan Vol. 11, No. 1, April 2010. UPI, Bandung.

Wahyudin, D. \& Susilana, R. (2012). Kurikulum \& Pembelajaran: Inovasi Kurikulum dan Pembelajaran. Jakarta: Rajawali Pers. 